\title{
Survival of the Qaidam mega-lake system under mid-Pliocene climates and its restoration under future climates
}

\author{
Dieter Scherer \\ Chair of Climatology, Technische Universität Berlin, Berlin 12165, Germany \\ Correspondence: Dieter Scherer (dieter.scherer@tu-berlin.de)
}

Received: 7 September 2019 - Discussion started: 23 October 2019

Revised: 20 June 2020 - Accepted: 26 June 2020 - Published: 29 July 2020

\begin{abstract}
The Qaidam Basin in the north of the Tibetan Plateau has undergone drastic environmental changes during the last millions of years. During the Pliocene, the Qaidam Basin contained a freshwater mega-lake system although the surrounding regions showed increasingly arid climates. With the onset of the Pleistocene glaciations, lakes began to shrink and finally disappeared almost completely. Today, hyperarid climate conditions prevail in the low-altitude parts of the Qaidam Basin. The question of how the mega-lake system was able to withstand the regional trend of aridification for millions of years has remained enigmatic so far. This study reveals that the mean annual water balance, i.e. the mean annual change in terrestrial water storage in the Qaidam Basin, is nearly zero under present climate conditions due to positive values of net precipitation in the high mountain ranges and shows positive annual values during warmer, less dry years. This finding provides a physically based explanation for how mid-Pliocene climates could have sustained the mega-lake system and that near-future climates not much different from present conditions could cause water storage in reservoirs, raising lake levels and expanding lake areas, and may even result in restoration of the mega-lake system over geological timescales. The study reveals that a region discussed as being an analogue to Mars due to its hyperarid environments is at a threshold under present climate conditions and may switch from negative values of long-term mean annual water balance that have prevailed during the last 2.6 million years to positive ones in the near future.
\end{abstract}

\section{Introduction}

Paleogeographic studies (Chen and Bowler, 1986; Huang et al., 1993; Mischke et al., 2010; Wang et al., 2012; Fang et al., 2016) on the intermontane endorheic Qaidam Basin (QB), located in China's desert region in the north of the Tibetan Plateau (TP), revealed that it once contained a mega-lake system during the mid-Pliocene (ca. 3.3-3.0 Ma BP) and before. Although spatial details of the mega-lake system are not known, Chen and Bowler (1986) reported that the total lake surface was about $59000 \mathrm{~km}^{2}$ during the early Pleistocene. The onset of the Pleistocene glaciations at ca. 2.6 MaBP marked a period of increased variability of climate, lake level and extent, as well as changes in salinity (Huang et al., 1993; Wang et al., 2012; An et al., 2001; Heermance et al., 2013; Fang et al., 2016). The mega-lake system finally disappeared during the last $100 \mathrm{ka}$ (Madsen et al., 2014; Yu et al., 2019). Today, only a few saline lakes and playas exist, and the lowaltitude parts of the QB are hyperarid deserts (Chen and Bowler, 1986; Huang et al., 1993; Wang et al., 2012).

Paleoclimate studies (e.g. An et al., 2001; Fang et al., 2007, 2016; Miao et al., 2013; Koutsodendris et al., 2019) could prove that climates in the region have become increasingly dry throughout the Pliocene. However, the existence of a mega-lake system during this period implies that longterm mean annual water balance $\Delta S$, i.e. the total annual change in terrestrial water storage within the basin's reservoirs (aquifers, soils, lakes, rivers, permafrost, snow covers, glaciers, etc.), was close to zero and did not show, on average, negative values over time periods of thousands of years or longer, because otherwise the mega-lake system would have temporarily dried out and produced layers of evaporites. 
The water balance equation of a drainage basin can be written as

$\Delta S=P-\mathrm{ET}-R$,

where $P$ is precipitation and ET is actual evapotranspiration, both quantities spatially averaged over the area of the drainage basin. Total runoff is indicated by $R$, which is the sum of surface and groundwater runoff leaving the drainage basin. In this study, all quantities in Eq. (1) are expressed as volume water equivalent per area and time interval (in millimetres per month or $\mathrm{mma}^{-1}$ ).

For endorheic basins like the QB, surface runoff is zero by definition. Groundwater entering or leaving a basin is generally difficult to quantify but can be neglected for the water balance of large intermontane basins like the QB, which has an area of ca. $254000 \mathrm{~km}^{2}$. Thus, the change in terrestrial water storage $\Delta S$ of the QB can be approximated by

$\Delta S=P-\mathrm{ET}$.

The term $P-$ ET is, as in this study, often referred to as net precipitation (Morrow et al., 2011) and is sometimes called effective precipitation (Pritchard et al., 2019) or water availability (Greve et al., 2018). In this study, $\Delta S$ is called water balance and refers to the spatial average of net precipitation over the total area of the QB by applying Eq. (2).

This study addresses the research question of how mean annual water balance in the QB could have been zero or even positive over millions of years under very dry climates such that a mega-lake system could have been sustained. I hypothesize that the high mountain ranges in the QB receive sufficient precipitation such that negative values of net precipitation at lower altitudes due to very low amounts of precipitation are compensated by positive values of net precipitation at high altitudes. A second hypothesis that is tested in this study is that annual $\Delta S$ of the QB is positively sensitive to warmer climates, i.e. that positive anomalies in spatially averaged annual air temperature $T$ cause positive anomalies in annual $\Delta S$ under present geographic conditions. Knowing the value of the sensitivity $\frac{\partial \Delta S}{\partial T}$ of annual $\Delta S$ to changes in annual $T$ would allow for a first-order estimate of the water balance under different climates like those in the midPliocene or the future. This approach follows the general idea underlying studies that have linked climates of the past with those projected for the near future using the concept of climate sensitivity (e.g. Chandan and Peltier, 2018).

This study does, however, neither intend to reconstruct the climates or the hydrology of the past nor to make predictions for the future. So far, paleogeographic data like paleoaltitudes or paleo-hydrographic conditions of the $\mathrm{QB}$, or past large-scale atmospheric circulation patterns in High Mountain Asia, are not well constrained by observational data, making it difficult to use them as input in spatially detailed hydrological models. It is also difficult to quantify feedbacks in the hydrological cycle of the QB like an increase in ET due to increased lake area, changes in blocking of air masses under different orography, or changes in water recycling within the QB under more humid atmospheric conditions. Moreover, a physically based explanation for the proven long-term existence of the mega-lake system in the QB under dry climate conditions is sought.

Since the mid-Pliocene is often regarded as a past analogue for modern climate changes (Zubakov and Borzenkova, 1988; Haywood et al., 2016; Chandan and Peltier, 2018), this study also intends to provide a rational basis for assessing environmental changes that might be caused by climate changes as projected in this region for the future (Burke et al., 2018; Gu et al., 2018; Hui et al., 2018).

\section{Data and methods}

Figure 1 provides an overview of the QB and its surrounding regions in the north of the TP. The boundary of the QB was delineated by Lehner and Grill (2013) from a digital elevation model (DEM) derived from data of the Shuttle Radar Topography Mission (SRTM).

\subsection{Meteorological data from the High Asia Refined analysis}

Meteorological data for 14 hydrological years (2001-2014) covering the period from October 2000 to September 2014 were taken from the first version of the High Asia Refined analysis (HAR) data set (Maussion et al., 2011, 2014). In the study region, hydrological years start in October and are numbered by the calendar year to which January belongs (i.e. the hydrological year 2001 starts in October 2000). The HAR data set was produced by dynamical downscaling of global gridded atmospheric data of the National Centers for Environmental Prediction (NCEP) Operational Model Global Tropospheric Analyses (FNL) with the Weather Research and Forecasting (WRF) model version 3.3.1 to two regional domains of 30 and $10 \mathrm{~km}$ grid spacing as described by Maussion et al. $(2011,2014)$. In contrast to regional climate simulations, the WRF model is re-initialized every day and integrated only over $36 \mathrm{~h}$. Data of the first $12 \mathrm{~h}$ are discarded to avoid artefacts eventually caused by model spin-up. The resulting data covering a full day are thus strongly constrained by the observed large-scale state of the atmosphere. Temporal resolution of the HAR $10 \mathrm{~km}$ data set is $1 \mathrm{~h}(3 \mathrm{~h}$ for the HAR $30 \mathrm{~km}$ data set). HAR data used in this study were aggregated to monthly values. Monthly data for air temperature $T$ ( $2 \mathrm{~m}$ above ground) and specific humidity $q(2 \mathrm{~m}$ above ground), which are called climate drivers in this study, are monthly means, while monthly data of $P$, which comprises both rainfall $P_{\text {rain }}$ and snowfall $P_{\text {snow }}$, and of ET are monthly sums. Monthly values for $\Delta S$ were computed from monthly values of $P$ and ET spatially averaged over the QB by applying Eq. (2). Data were further aggregated to annual means 


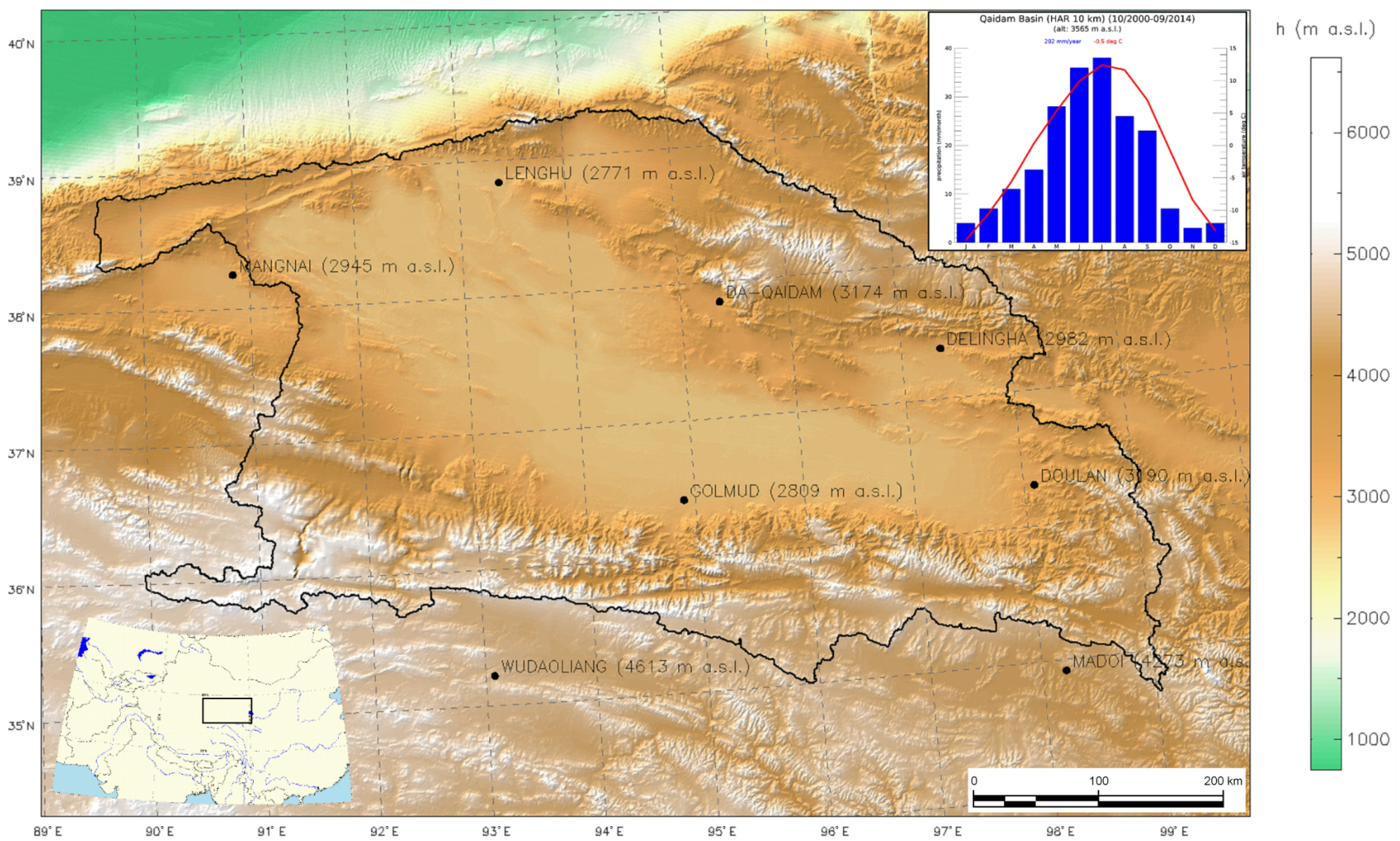

Figure 1. Overview of the Qaidam Basin (QB), including a spatially averaged climate diagram for the QB derived from the HAR $10 \mathrm{~km}$ data set for the study period of 14 hydrological years (2001-2014). Black line: boundary of the QB (Lehner and Grill, 2013). Topographic shading is based on DEM data from the SRTM. Black dots indicate the locations of the eight GSOD stations within or nearby the QB.

and sums for each hydrological year and to mean monthly and annual values for the 14-year study period, both for each of the 2543 grid points of the HAR $10 \mathrm{~km}$ data set (280 grid points in the HAR $30 \mathrm{~km}$ data set) and the spatial averages over the QB.

\subsection{Meteorological data from the Global Summary of the Day}

The National Centers for Environmental Information (formerly known as the National Climatic Data Center) of the National Oceanic and Atmospheric Administration (NOAA) provide the Global Summary of the Day (GSOD), which is a collection of meteorological data from numerous weather stations all over the world. Eight GSOD stations providing meteorological data for the entire study period are located within or nearby the QB as shown in Fig. 1. Only GSOD data that are not flagged as invalid were used in this study. The data set is used for a discussion of errors and uncertainties (see Sect. 4).

\subsection{Data on actual evapotranspiration}

A data set of annual ET values for the QB and eight hydrological subregions covering the time period from 2001 to
2011 (Jin et al., 2013) was used in this study to assess the results based on the HAR $10 \mathrm{~km}$ data set. The data set was derived from various data sources, especially from space-borne remote sensing data from the Moderate Resolution Imaging Spectroradiometer MODIS, by applying the Surface Energy Balance System (SEBS) algorithm (Su, 2002). The data set is used for a discussion of errors and uncertainties (see Sect. 4).

\subsection{Statistics}

Regression analyses as performed in this study are simple linear regressions and one multiple linear regression using the ordinary least squares method. Simple linear regressions, in which altitude $h$ was used as a predictor variable $x$, were performed both by using $x=h$ directly (in ma.s.l.) and by $x=e^{h^{*}}$, where $h^{*}=\frac{h}{h_{\text {scl }}}\left(h_{\text {scl }}=1000 \mathrm{~m}\right)$. The respective result with the highest effect size is used in this study. Probability values $p$ for significance testing of the regression results were computed from double-sided $t$ tests. Statistically significant results are assumed for $p<0.05$. The effect size of the regressions is specified by the coefficient of determination $r^{2}$, which is the fraction of variance in the dependent variable $y$ that is explained by the linear model of the predictor variable(s) $x$. The effect size is further specified by the 
adjusted $r^{2}\left(r_{\text {adj }}^{2}\right)$ :

$r_{\text {adj }}^{2}=1-\left(1-r^{2}\right) \frac{N-1}{N-k-1}$,

where $N$ is the number of observations (i.e. years; $N=14$ ), while $k$ is the number of predictor variables.

\section{Results}

In the following subsections, the study results are presented. First, annual values of the water balance of the QB are shown for the 14 years. Then, altitude dependencies of each quantity are presented for each grid point of the HAR $10 \mathrm{~km}$ data set within the QB. Finally, the results of a sensitivity study relating the water balance components to the climate conditions are shown.

\subsection{Water balance}

Table 1 lists mean monthly and annual values for the water balance components and the climate drivers, while Fig. 2 presents time series of the annual values of $P$, ET, and $\Delta S$ for the 14 years covered by this study. The results show that the QB's water balance is nearly zero $\left(\Delta S=-14 \pm 34 \mathrm{~mm} \mathrm{a}^{-1}\right)$ under present climate conditions. From 2005 to 2012, all years except 2011 show above-average annual values for the water balance due to increased annual precipitation. Rainfall is the main driver of interannual variability of both precipitation and water balance, while snowfall and actual evapotranspiration are less variable. The first year (2001) was the one with by far the most negative water balance $(\Delta S=$ $\left.-94 \mathrm{~mm} \mathrm{a}^{-1}\right)$, was also the coldest $\left(T=-1.6^{\circ} \mathrm{C}\right)$ and driest $\left(q=2.2 \mathrm{~g} \mathrm{~kg}^{-1}\right)$ year, and received the lowest amount of precipitation $\left(P=122 \mathrm{mma}^{-1}\right)$, rainfall $\left(P_{\text {rain }}=45 \mathrm{~mm} \mathrm{a}^{-1}\right)$, and snowfall $\left(P_{\text {snow }}=77 \mathrm{~mm} \mathrm{a}^{-1}\right)$ (see Tables S1-S7 in the Supplement for monthly and annual values for each quantity and year).

Mean monthly values for the quantities shown in Table 1 illustrate strong differences in their seasonality. While $T, q$, $P, P_{\text {rain }}, P_{\text {snow }}$, and to a lesser extent also ET show strong variations over the year with slightly displaced winter minima and summer maxima, $\Delta S$ is less variable during the course of the year. This indicates complex interdependencies between the climate drivers and the water balance components, which lead to partial compensatory effects. Concurrence of the summer maxima of air temperature and precipitation in July leads to a shift of the maximum of snowfall to May, since higher air temperatures during summer reduce the fraction of precipitation falling as snow. The cold months are connected with a slightly negative monthly water balance due to sublimation of snow exceeding snowfall. The concurrently higher values of precipitation and actual evapotranspiration during summer mostly compensate for each other such that monthly water balance is only slightly positive during early summer. In August monthly water balance even shows small water losses since precipitation decreases faster than actual evapotranspiration.

\subsection{Altitude dependencies}

Altitude dependencies of the annual water balance components and the climate drivers are presented in Fig. 3. While $T, P, P_{\text {snow }}$, and $P-$ ET show strong correlations with altitude $h$ within the QB, ET is only weekly correlated with $h$, and $q$ is not dependent on $h$. At altitudes of $4000 \mathrm{~m}$ a.s.l. and higher, net precipitation becomes positive on average, and none of the HAR $10 \mathrm{~km}$ grid points shows negative values above $4700 \mathrm{~m}$ a.s.l., which demonstrates the importance of high mountains as water towers (Xu et al., 2008) for the hydrology of the QB, especially under arid climates like those in the desert zones of High Mountain Asia.

Figure 3 illustrates that the air over the lakes (10 grid points in the HAR $10 \mathrm{~km}$ data set) is generally warmer and less dry than over land, which is the result of high actual evapotranspiration due to lake evaporation. Mean annual values for $T, q, P, P_{\text {snow }}$, ET, and $P-$ ET averaged over the 10 lake grid points are $0.7^{\circ} \mathrm{C}, 4.6 \mathrm{~g} \mathrm{~kg}^{-1}$, $153 \mathrm{mma}^{-1}, 60 \mathrm{mma}^{-1}, 649 \mathrm{mma}^{-1}$, and $-496 \mathrm{mma}^{-1}$, while the respective values for the land grid points are $-0.5^{\circ} \mathrm{C}, 2.6 \mathrm{~g} \mathrm{~kg}^{-1}, 201 \mathrm{~mm} \mathrm{a}^{-1}, 103 \mathrm{~mm} \mathrm{a}^{-1}, 212 \mathrm{~mm} \mathrm{a}^{-1}$, and $-12 \mathrm{~mm} \mathrm{a}^{-1}$.

Although there are a few low-lying areas with very high actual evapotranspiration, the majority of land areas show increasing actual evapotranspiration with altitude, while air temperature strongly decreases with altitude (following the mean annual moist-adiabatic lapse rate). This indicates that abundance of water but not available energy for latent heat is the main limiting factor for actual evapotranspiration in the QB. In fact, the areas showing high actual evapotranspiration are mainly saline lakes that are not indicated as lakes in the HAR $10 \mathrm{~km}$ data set, such that water is available for actual evapotranspiration.

Lakes tend to suppress rainfall and snowfall such that their annual values are lower over lakes. In consequence, most lakes ( 7 of 10 grid points) show strongly negative net precipitation. Further details and maps of the spatial patterns of the water balance components and the climate drivers are presented in Figs. S1 to S7 in the Supplement.

\subsection{Sensitivity study}

Figure 4 presents results of simple linear regression analyses between annual values of the spatially averaged quantities for the entire QB for the 14 hydrological years, which reveal that annual variability of water balance is driven by precipitation but not by actual evapotranspiration. Both precipitation and water balance are themselves driven by air temperature and specific humidity, the latter showing much stronger effect sizes in the simple linear regressions. 
Table 1. Mean monthly and annual air temperature $T$ (in ${ }^{\circ} \mathrm{C}$ ), specific humidity $q$ (in $\mathrm{g} \mathrm{kg}^{-1}$ ), precipitation $P$ (in millimetres per month or millimetres per year), rainfall $P_{\text {rain }}$ (in millimetres per month or millimetres per year), snowfall $P_{\text {snow }}$ (in millimetres per month or millimetres per year), actual evapotranspiration ET (in millimetres per month or millimetres per year), and water balance $\Delta S=P-$ ET (in millimetres per month or millimetres per year) in the Qaidam Basin (QB) derived from the HAR $10 \mathrm{~km}$ data set; Sigma: standard deviations of annual values for each quantity during the hydrological years 2001 to 2014 .

\begin{tabular}{lrrrrrrrrrrrrrr}
\hline Month & 10 & 11 & 12 & 1 & 2 & 3 & 4 & 5 & 6 & 7 & 8 & 9 & Year & Sigma \\
\hline$T$ & -0.7 & -8.4 & -13.1 & -14.6 & -10.5 & -5.6 & 0.3 & 5.3 & 9.9 & 12.4 & 11.6 & 7.0 & -0.5 & 0.6 \\
$q$ & 2.2 & 1.4 & 1.0 & 0.9 & 1.2 & 1.5 & 1.9 & 2.8 & 4.3 & 5.6 & 5.1 & 3.9 & 2.7 & 0.2 \\
$P$ & 7 & 3 & 4 & 4 & 7 & 11 & 15 & 28 & 36 & 38 & 26 & 23 & 200 & 43 \\
$P_{\text {rain }}$ & 1 & 0 & 0 & 0 & 1 & 1 & 4 & 9 & 21 & 30 & 19 & 12 & 97 & 31 \\
$P_{\text {snow }}$ & 6 & 3 & 4 & 4 & 6 & 10 & 11 & 19 & 15 & 8 & 7 & 11 & 103 & 17 \\
ET & 13 & 8 & 5 & 5 & 9 & 15 & 18 & 25 & 29 & 34 & 31 & 21 & 214 & 18 \\
$\Delta S$ & -6 & -4 & -1 & -2 & -2 & -4 & -4 & 2 & 7 & 4 & -5 & 1 & -14 & 34 \\
\hline
\end{tabular}

Since annual air temperature and specific humidity are themselves correlated $\left(r^{2}=0.571 ; r_{\text {adj }}^{2}=0.535 ; p<0.01\right.$; see Fig. S8 in the Supplement), the problem of multicollinearity of the two climate drivers was addressed in this study by an additional multiple linear regression in which both annual $T$ and $q$ serve as predictor variables, while annual $\Delta S$ is taken as the dependent variable. Both predictors together explain more than $85 \%$ of the variance in annual $\Delta S\left(r^{2}=0.852 ; r_{\text {adj }}^{2}=0.825 ; p<0.001\right)$. However, the analysis revealed that the unique contribution of annual air temperature to the variance in the annual water balance is not significant. Air temperature alone uniquely explains only $0.25 \%\left(p_{T}=0.67\right)$ of the variance in water balance, while the unique variance explanation by specific humidity is $31.96 \%\left(p_{q}<0.001\right)$. The combined effect of air temperature and specific humidity explains $52.97 \%$. Thus, the simple linear regression between specific humidity and water balance as shown in Fig. $4 \mathrm{f}$ accounts for both direct and indirect effects of variations in annual specific humidity on the annual water balance of the QB.

The results show that a change in annual specific humidity of $1.0 \mathrm{~g} \mathrm{~kg}^{-1}$ would lead to an estimated change in annual water balance of $131 \mathrm{~mm} \mathrm{a}^{-1}$. Since the standard error of the estimate for annual water balance is $14.0 \mathrm{~mm} \mathrm{a}^{-1}$, even a slight change in annual specific humidity of e.g. $0.2 \mathrm{~g} \mathrm{~kg}^{-1}$ would have a strong, significant effect such that annual water balance of the QB would become positive.

\section{Discussion}

\subsection{Errors and uncertainties}

Physical consistency of the results obtained from the HAR data set is ensured by the fact that the WRF model is physically based, and HAR data have been comprehensively analysed, particularly with respect to precipitation and atmospheric water transport (Maussion et al., 2011, 2014; Curio et al., 2015; Pritchard et al., 2019; Yoon et al., 2019; Bai et al., 2020). HAR data have been successfully utilized for e.g. studying glacier mass balance on the TP (Mölg et al., 2014), in which independent data sets from global reanalysis data and field measurements have also been included to ensure validity of the results. Pritchard et al. (2019) showed for the upper Indus basin that the HAR $10 \mathrm{~km}$ data set is particularly applicable in studies on water availability. Li et al. (2020) state that “... the two HAR data sets performed better at capturing the average precipitation in high-altitude areas than the other seven data sets...".

Since the HAR data set, as any data set, comes with errors and uncertainties, the question arises how they would influence the results of the study. Figure 3 illustrates that at six of the eight GSOD stations within or nearby the QB the HAR $10 \mathrm{~km}$ precipitation data are well according to the measurements, while precipitation might be slightly underestimated at two GSOD stations by the HAR $10 \mathrm{~km}$ data. The altitudinal changes in both air temperature and precipitation as documented by the GSOD data are well captured by the HAR $10 \mathrm{~km}$ data. A comparison of HAR $10 \mathrm{~km}$ results for actual evapotranspiration with those from the SEBS-based study by Jin et al. (2013) indicates higher actual evapotranspiration in the HAR $10 \mathrm{~km}$ data. During the calendar years from 2005 to 2011, mean annual actual evapotranspiration is $218 \mathrm{~mm} \mathrm{a}^{-1}$ in the HAR $10 \mathrm{~km}$ data, while SEBS data show $153 \mathrm{mma}^{-1}$. Both annual time series are well correlated during this time period $\left(r^{2}=0.733 ; r_{\mathrm{adj}}^{2}=0.679 ; p<0.05\right.$; see Fig. S9 and Table S8 in the Supplement). SEBS shows inconsistent, even lower actual evapotranspiration values during the calendar years 2001 to 2004 (HAR $10 \mathrm{~km}$ : ET $=202 \mathrm{~mm} \mathrm{a}^{-1}$; SEBS: ET $=77 \mathrm{mma}^{-1}$; see Table S8 in the Supplement). These findings reveal that there is no evidence that the HAR $10 \mathrm{~km}$ data set would overestimate annual water balance of the QB. On the contrary, if SEBS values for annual actual evapotranspiration would be considered to be more accurate than the HAR $10 \mathrm{~km}$ data, then annual water balance would have been positive throughout all years. 

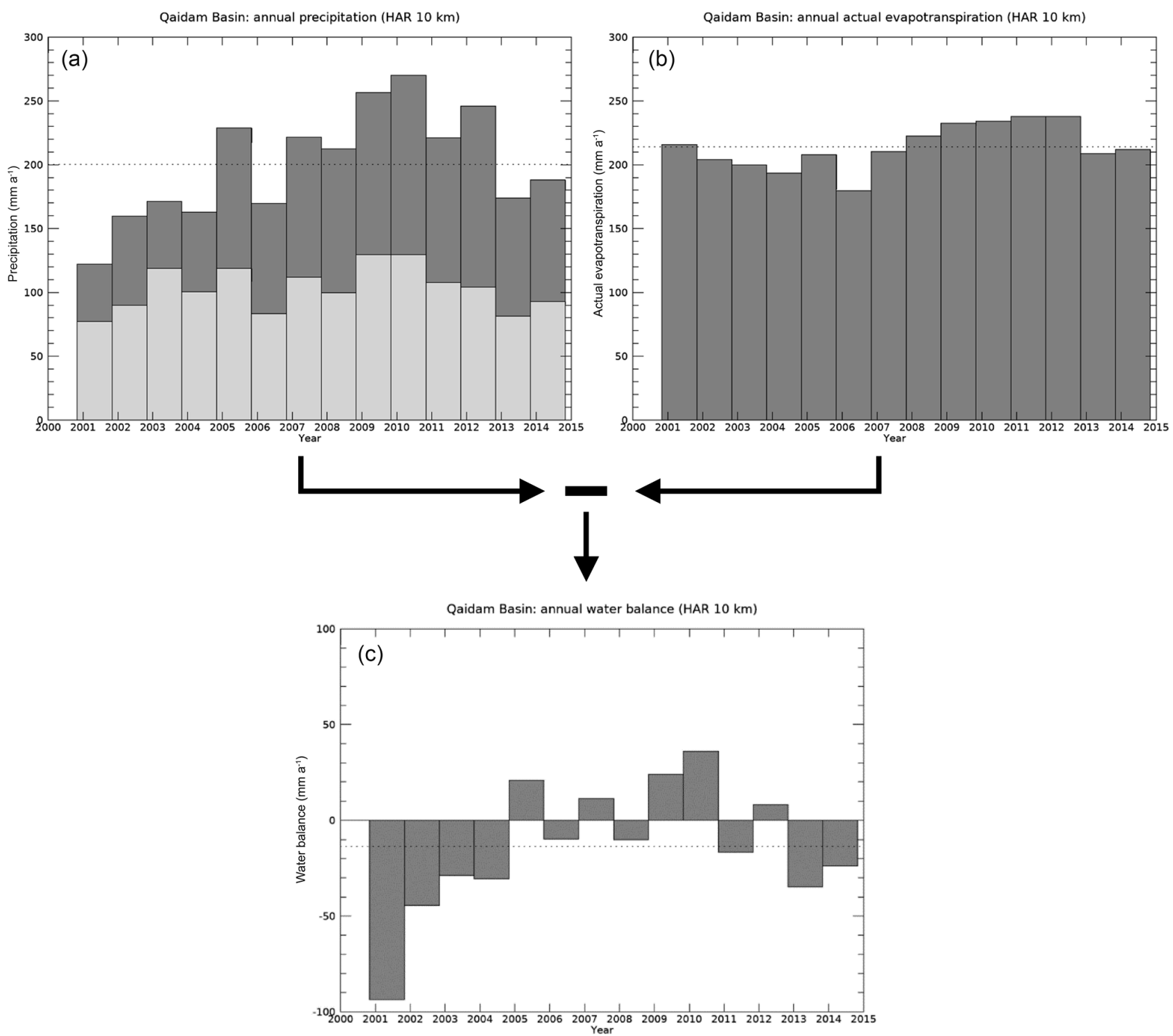

Figure 2. Annual precipitation (a), actual evapotranspiration (b), and water balance (c) in the Qaidam Basin (QB) during the hydrological years 2001 to 2014 derived from the HAR $10 \mathrm{~km}$ data set. (a) Light grey bars: annual snowfall; dark grey bars: annual rainfall. Dotted lines: mean annual values.

\subsection{Comparison with other studies}

The results of this study are in accordance with results from other studies. A number of studies (Liu and Chen, 2000; Kang et al., 2010; Li et al., 2010; L. Zhang et al., 2013) revealed that the TP experiences general but spatially and temporally varying trends to higher air temperatures, increasing humidity, and precipitation, which are also found in the QB (Wang et al., 2014). The regions in Qinghai Province, to which the QB belongs, show trends to warmer and wetter climates, while those regions belonging to Tibet tend to warmer but dryer climates (L. Zhang et al., 2013). However, recent precipitation trends and subsequent environmental changes show complex spatial and temporal patterns, such that wetting is also taking place in several regions of Tibet (see e.g. Yang et al., 2014; Y. Li et al., 2019), including endorheic basins in interior Tibet.

Several studies (Zhang et al., 2011; G. Zhang et al., 2013, 2017; Lei et al., 2014; H. Li et al., 2019; Y. Li et al., 2019) reported on rising lake levels and expanding lake areas on the TP. Besides enhanced glacier melt, increasing precipitation is regarded as the main driver of rising lake levels (G. Zhang et al., 2013, 2017; Lei et al., 2014; Y. Li et al., 2019). The total lake area in the QB increased from $994 \mathrm{~km}^{2}$ in the 1960 s to $1046 \mathrm{~km}^{2}$ in 2014 (Wan et al., 2016), and the number of lakes increased (H. Li et al., 2019) by 18 from 1977 to 2015. These findings further show that HAR $10 \mathrm{~km}$ data do not overesti- 


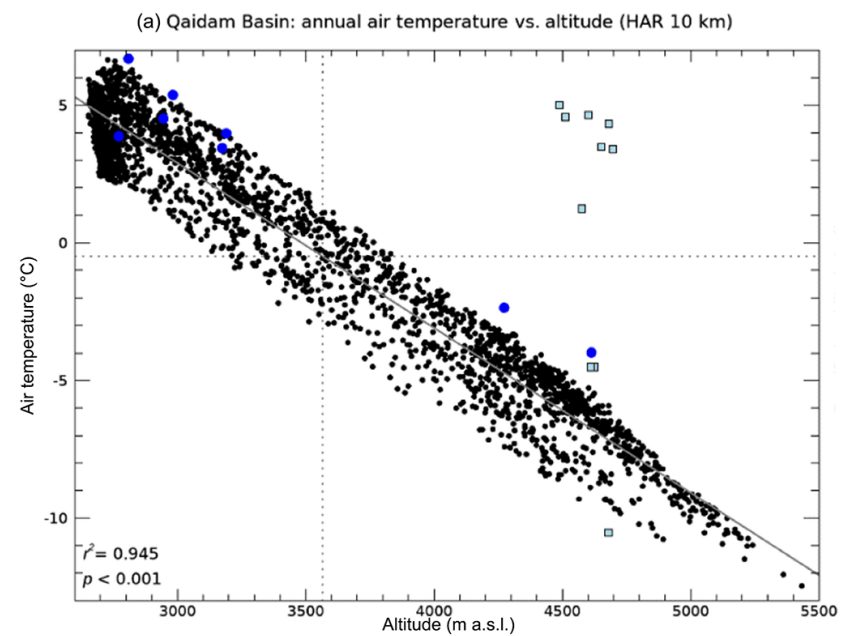

(c) Qaidam Basin: annual precipitation vs. altitude (HAR $10 \mathrm{~km}$ )

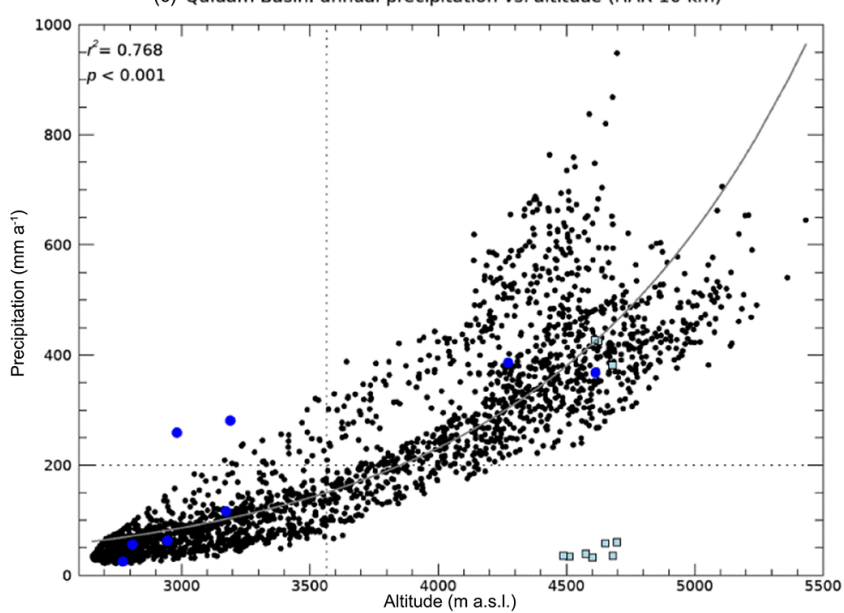

(e) Qaidam Basin: annual actual evapotranspiration vs. altitude (HAR $10 \mathrm{~km}$ )

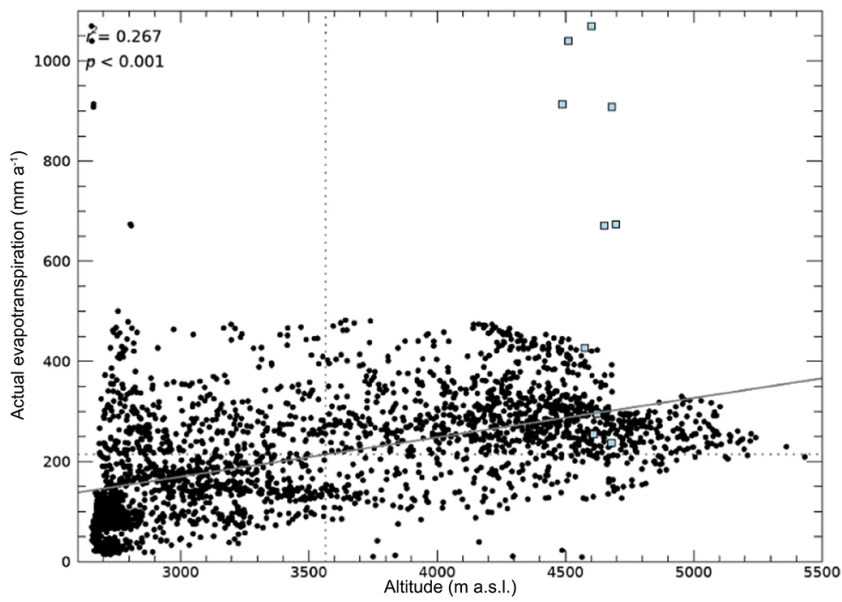

(b) Qaidam Basin: annual specific humidity vs. altitude (HAR $10 \mathrm{~km}$ )

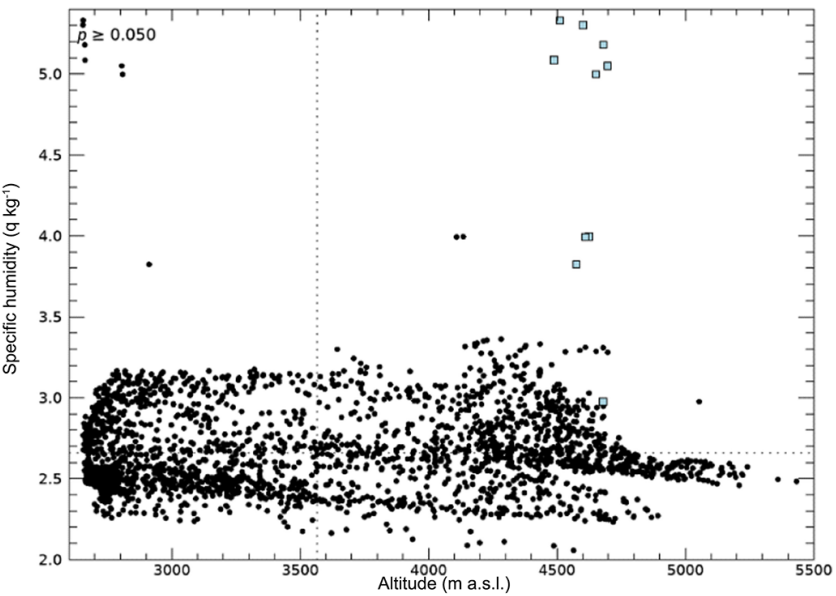

(d) Qaidam Basin: annual snowfall vs. altitude (HAR $10 \mathrm{~km}$ )

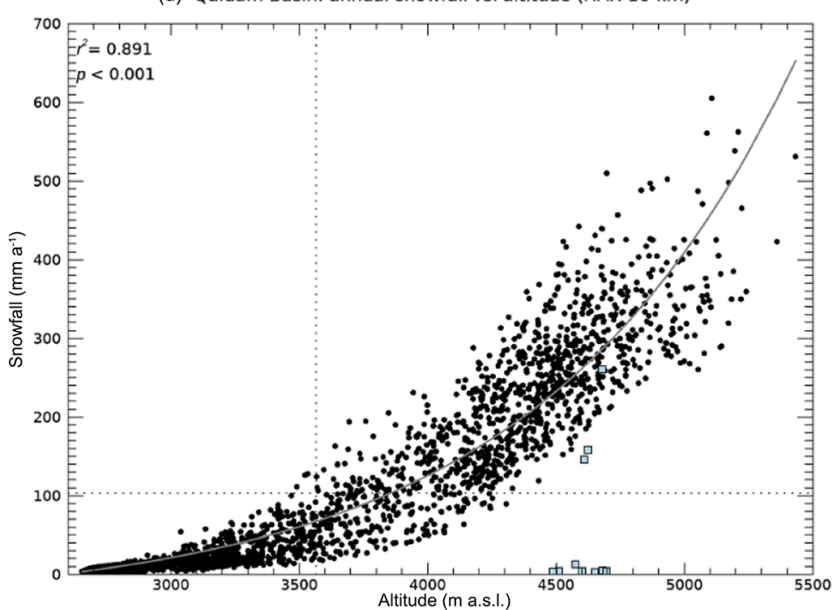

(f) Qaidam Basin: annual net precipitation vs. altitude (HAR $10 \mathrm{~km}$ )

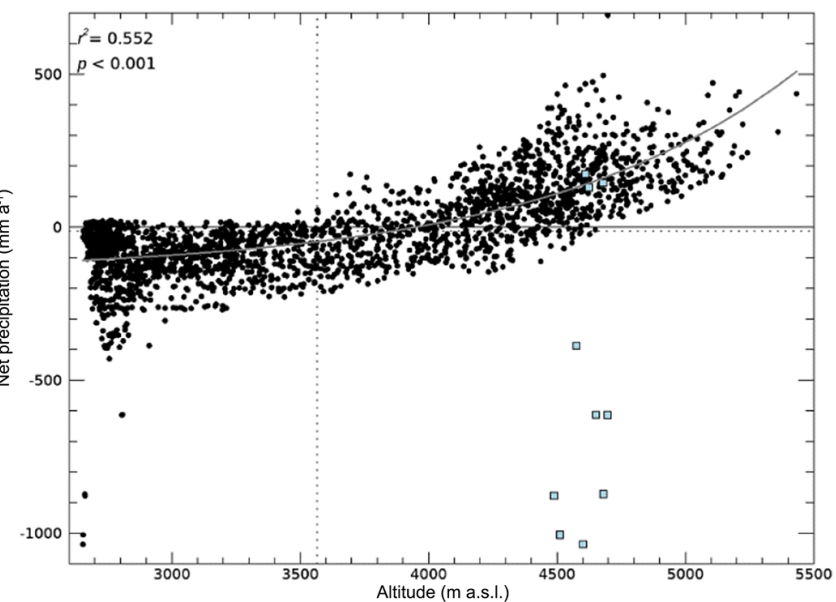

Figure 3. Mean annual air temperature (a), specific humidity (b), precipitation (c), snowfall (d), actual evapotranspiration (e), and net precipitation (f) versus altitude in the Qaidam Basin (QB) during the hydrological years 2001 to 2014 derived from the HAR $10 \mathrm{~km}$ data set. Black dots: land grid points; light blue squares: grid points covered by lakes in the HAR $10 \mathrm{~km}$ land cover data; blue dots: data from eight GSOD stations; dotted lines: mean annual values. 
(a) Qaidam Basin: annual water balance vs. precipitation (HAR $10 \mathrm{~km}$ )

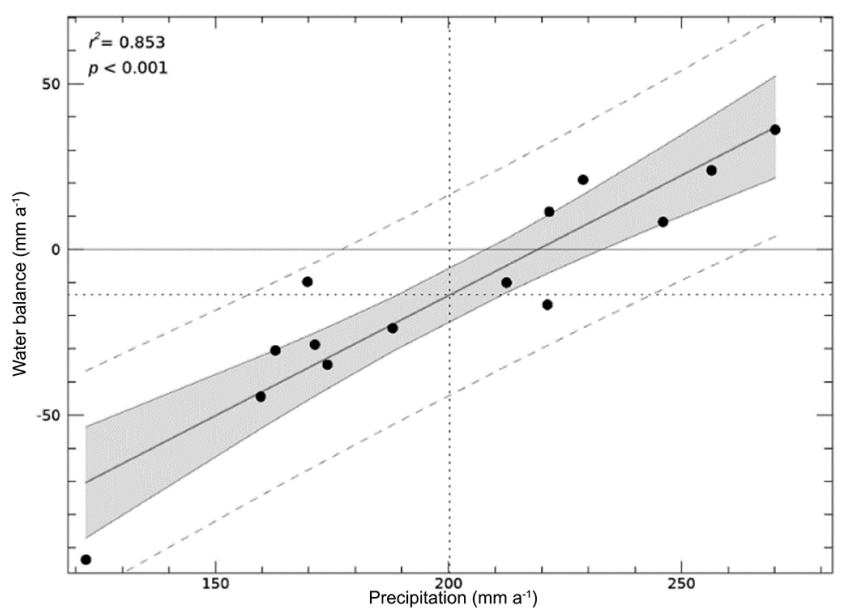

(c) Qaidam Basin: annual precipitation vs. air temperature (HAR $10 \mathrm{~km}$ )

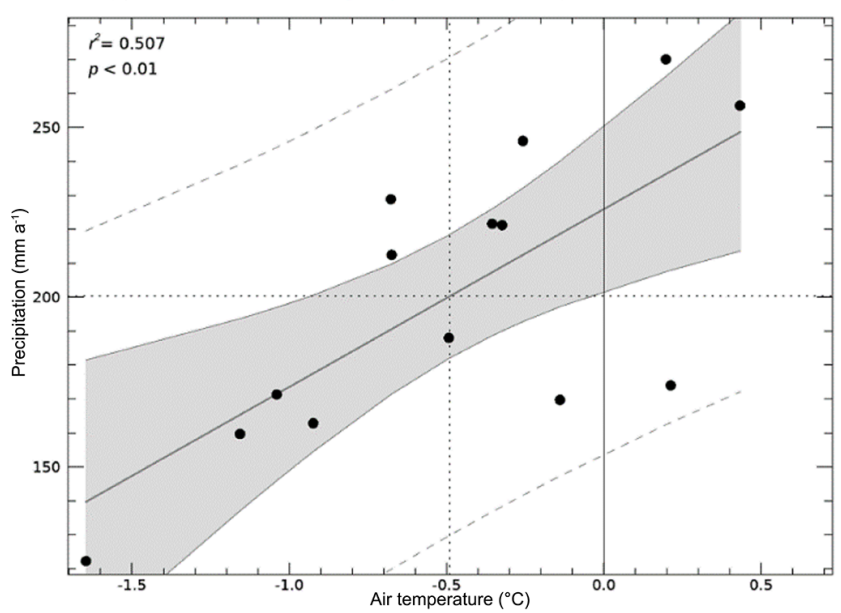

(e) Qaidam Basin: annual water balance vs. air temperature (HAR $10 \mathrm{~km}$ )

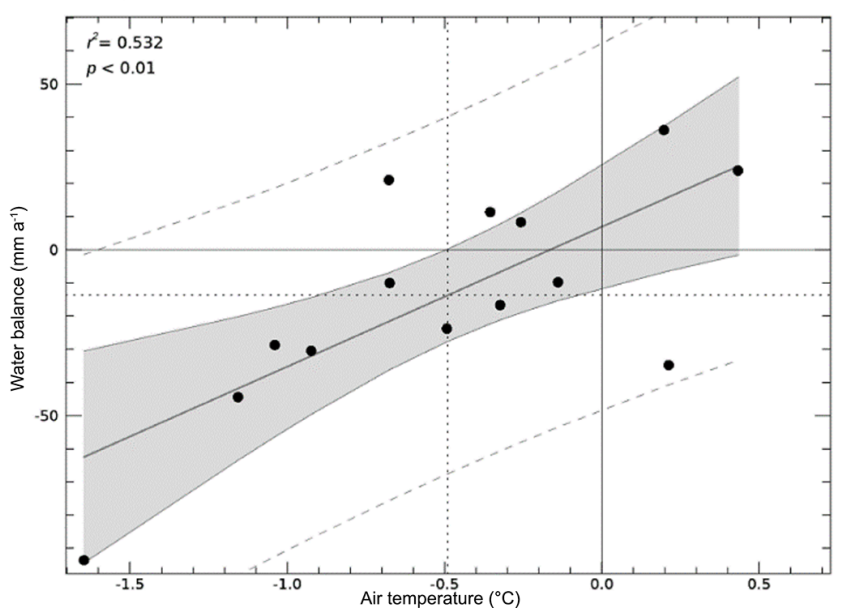

(b) Qaidam Basin: annual water balance vs. actual evapotranspiration (HAR $10 \mathrm{~km}$ )

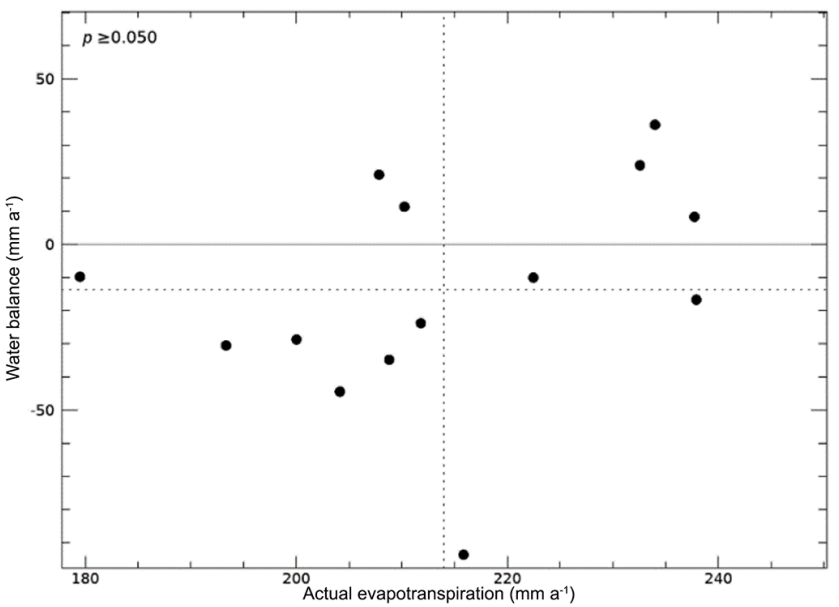

(d) Qaidam Basin: annual precipitation vs. specific humidity (HAR $10 \mathrm{~km}$ )

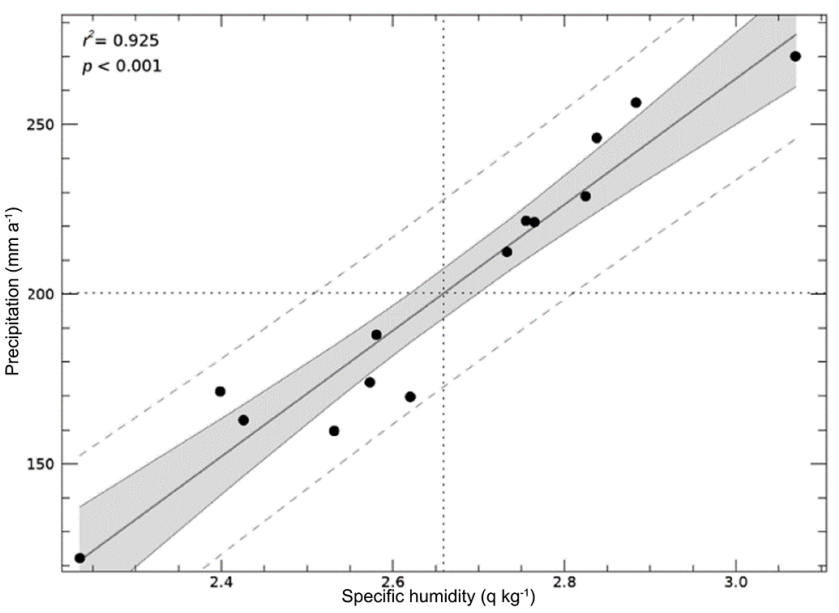

(f) Qaidam Basin: annual water balance vs. specific humidity (HAR $10 \mathrm{~km}$ )

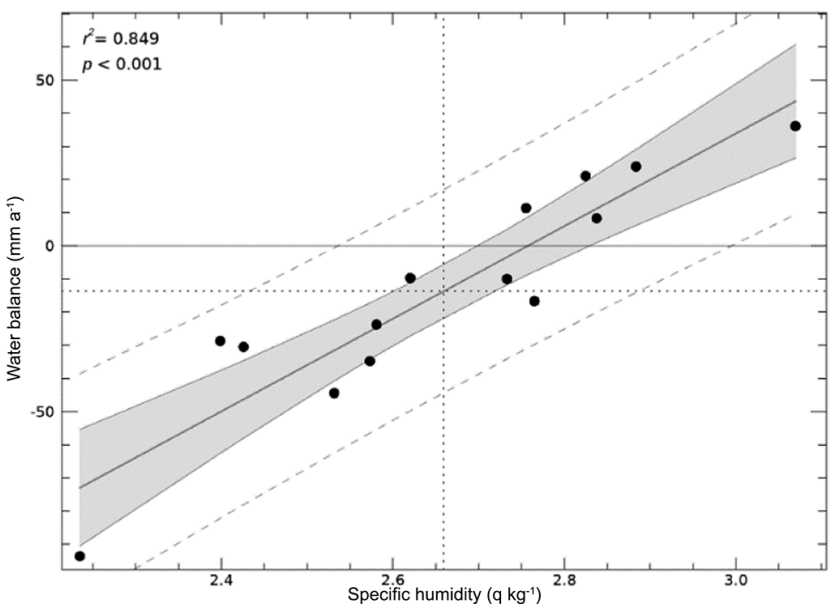

Figure 4. Water balance versus precipitation (a) and actual evapotranspiration (b); precipitation versus air temperature (c) and specific humidity (d); water balance versus air temperature (e) and specific humidity (f) in the Qaidam Basin (QB) during the hydrological years 2001 to 2014 derived from the HAR $10 \mathrm{~km}$ data set. Dotted lines: mean annual values; solid lines: regression lines; light grey shades: confidence intervals; dashed lines: prediction intervals. 
mate annual water balance in the QB, because lake growth indicates positive water balance.

Increased terrestrial water storage in the QB affects not only lakes, but also groundwater reservoirs. Jiao et al. (2015) showed for the QB that aquifers were recharged between 2003 and 2012 due to a change in terrestrial water storage of $20.6 \mathrm{~km}^{3}$, which is equivalent to a slightly positive mean annual water balance of $8 \mathrm{mma}^{-1}$ during this time period, while the mean value from the HAR $10 \mathrm{~km}$ data set for the same time period is only slightly lower and amounts to $0 \mathrm{mma}^{-1}$. This result is also confirmed by the study of Loomis et al. (2019), who show zero to slightly positive mass trends in the northern TP.

\subsection{Implications for the mid-Pliocene and the future}

During the mid-Pliocene, climates were generally warmer and less dry (or wetter) than today in many regions of the world (Haywood et al., 2013, 2016). The studies of R. Zhang et al. (2013) and Mutz et al. (2018) provide quantitative estimates of mid-Pliocene changes in mean annual air temperature and precipitation with respect to preindustrial climates from various global paleoclimate simulations. The study of R. Zhang et al. (2013) is based on a multi-model ensemble, which showed approximately 2 to $4 \mathrm{~K}$ higher mean annual air temperature in the QB during the mid-Pliocene as inferred from their Fig. 6. The same Fig. 6 indicates 100 to $300 \mathrm{~mm} \mathrm{a}^{-1}$ higher values for mean annual precipitation. The study of Mutz et al. (2018) is based on simulations by a single global model, showing 2 to $6 \mathrm{~K}$ higher mean annual air temperature in the high mountains, while it was approximately 2 to $4 \mathrm{~K}$ cooler in the lower parts of the QB as inferred from their Fig. 4. Mean annual precipitation was approximately 100 to $300 \mathrm{~mm} \mathrm{a}^{-1}$ higher as shown in the same Fig. 4. Both studies did not present data on differences between preindustrial and present times. Nevertheless, the values for mean annual air temperature and precipitation as presented by Fig. 4 in Mutz et al. (2018) are generally comparable to those from the HAR $10 \mathrm{~km}$ data set. Thus, present mean annual air temperature is assumed to be slightly higher (about $1 \mathrm{~K}$ ) than during preindustrial times, such that changes in air temperature between the mid-Pliocene and present times are slightly lower but still positive (at least $1 \mathrm{~K}$ higher than today). Analogously, changes in precipitation are assumed to follow the same pattern (at least $50 \mathrm{~mm} \mathrm{a}^{-1}$ higher than today).

Table 2 presents estimates for mean annual changes in the water balance of the QB due to climate changes with respect to present conditions. The first three rows (marked in red) indicate changes $\Delta q, \Delta P$, and $\Delta(\Delta S)$ for estimates of minimum and maximum changes in annual air temperature $\Delta T$. As conservative estimates, minimum and maximum changes in annual air temperature were set to 1 and $2 \mathrm{~K}$, respectively, which can be used as estimates for the air temperature range representing both mid-Pliocene climates and those projected for the end of the 21st century (Burke et al., 2018; Gu et al.,
2018; Hui et al., 2018). Applying the results from the simple linear regressions (Fig. 4) providing estimates for the sensitivities $\frac{\partial q}{\partial T}, \frac{\partial P}{\partial T}$, and $\frac{\partial \Delta S}{\partial T}$, the estimated changes in annual precipitation due to changes in annual air temperature would be 52 to $105 \mathrm{mma}^{-1}$, which are compatible with the values modelled for the mid-Pliocene by R. Zhang et al. (2013) and by Mutz et al. (2018). The estimated change in annual water balance as inferred from the changes in mean annual air temperature would lead to a positive mean annual water balance of $49 \mathrm{mma}^{-1}$. Based on the same estimates for changes in annual air temperature and the sensitivity of annual specific humidity to changes in annual air temperature, the resulting changes in annual specific humidity would be between 0.3 and $0.6 \mathrm{~g} \mathrm{~kg}^{-1}$.

Applying the sensitivities of annual precipitation $\frac{\partial P}{\partial q}$ and water balance $\frac{\partial \Delta S}{\partial q}$ with respect to changes in annual specific humidity (fourth and fifth rows in Table 2; marked in blue), the resulting changes in annual precipitation and water balance would be almost identical (values differ only by $3 \mathrm{mma}^{-1}$ or less) to those directly estimated from the changes in annual air temperature.

The sixth row of Table 2 (marked in black) shows the results for changes in annual water balance $\Delta(\Delta S)$ for given changes in annual precipitation $\Delta P$. Minimum and maximum values for the changes in annual precipitation (50 to $100 \mathrm{mma}^{-1}$ ) are conservative estimates but also compatible with the studies of R. Zhang et al. (2013) and Mutz et al. (2018). The mean change in annual water balance as inferred from the changes in annual precipitation by applying the sensitivity of annual water balance to changes in annual precipitation $\frac{\partial \Delta S}{\partial P}$ would lead to a positive mean annual water balance of $40 \mathrm{~mm} \mathrm{a}^{-1}$.

Warmer and less dry conditions in the QB are also confirmed from geological evidence (Miao et al., 2013; Wu et al., 2011; Cai et al., 2012). The very high sensitivity of annual water balance to changes in annual air temperature and specific humidity as revealed in this study would explain that even slightly warmer and less dry climates could result in positive long-term mean annual water balance such that the mega-lake system could have been able to exist in this still very dry region for long time.

It must, however, be noted that these estimates do not consider feedbacks that will have additional effects on the water balance of the QB. At a certain point, lake area will not be able to increase further since increasing lake evaporation would drop positive to zero mean annual water balance. This feedback mechanism was analysed in this study by a semiempirical model (see the R source code in the Supplement) to provide first-order estimates of the effects of changes in lake extent and mean annual precipitation in the QB on actual evapotranspiration, net precipitation, runoff from land areas to lakes, as well as water storage and associated lake-level changes in the QB. The model considers that an enlarged lake area would increase total ET in the QB, since lake evapora- 
Table 2. Estimated changes in annual air temperature $\Delta T$ (in ${ }^{\circ} \mathrm{C}$ ), specific humidity $\Delta q$ (in $\mathrm{g} \mathrm{kg}^{-1}$ ), precipitation $\Delta P$ (in mma ${ }^{-1}$ ), and water balance $\Delta(\Delta S)$ (in $\mathrm{mm} \mathrm{a}^{-1}$ ) in the Qaidam Basin $(\mathrm{QB})$ with respect to present conditions and resulting estimated annual water balance $\Delta S$ (in $\mathrm{mma}^{-1}$ ) for the mid-Pliocene. Red colours: estimates based on changes $\Delta T$; blue colours: estimates based on changes $\Delta q$; black colours: estimates based on changes $\Delta P$. Input values for $\Delta T$ (magenta shades) and $\Delta P$ (grey shades) are estimates based on the studies of R. Zhang et al. (2013) and Mutz et al. (2018), while present values and sensitivities are derived from the HAR $10 \mathrm{~km}$ data set during the hydrological years 2001 to 2014 as discussed in the text.

\begin{tabular}{|c|c|c|c|c|c|c|c|c|c|c|c|c|c|}
\hline \multirow[b]{2}{*}{ sensitivity } & \multirow[b]{2}{*}{ value } & \multirow[b]{2}{*}{ unit } & \multicolumn{2}{|c|}{$\Delta T$} & \multicolumn{2}{|c|}{$\Delta q$} & \multicolumn{2}{|c|}{$\Delta P$} & \multicolumn{2}{|c|}{$\Delta(\Delta S)$} & \multicolumn{3}{|c|}{$\Delta S$} \\
\hline & & & $\min$ & $\max$ & $\min$ & $\max$ & $\min$ & $\max$ & $\min$ & $\max$ & $\min$ & $\max$ & mean \\
\hline$\frac{\partial q}{\partial T}$ & 0.288 & $\mathrm{~g} \mathrm{~kg}^{-1} \mathrm{~K}^{-1}$ & 1.0 & 2.0 & 0.3 & 0.6 & & & & & & & \\
\hline$\frac{\partial P}{\partial T}$ & 52.40 & $\mathrm{~mm} \mathrm{a}^{-1} \mathrm{~K}^{-1}$ & & & & & 52 & 105 & & & & & \\
\hline$\frac{\partial \Delta S}{\partial T}$ & 42.17 & $\mathrm{~mm} \mathrm{a}^{-1} \mathrm{~K}^{-1}$ & & & & & & & 42 & 84 & 28 & 70 & 49 \\
\hline $\begin{array}{l}\frac{\partial P}{\partial q} \\
\frac{\partial \Delta S}{\partial q}\end{array}$ & 185.6 & $\begin{array}{l}\mathrm{mm} \mathrm{a}^{-1} \mathrm{~g} \mathrm{~kg}^{-1} \\
\mathrm{~mm} \mathrm{a}^{-1} \mathrm{~g} \mathrm{~kg}^{-1}\end{array}$ & & & 0.3 & 0.6 & 53 & 107 & 40 & 81 & 26 & 67 & 46 \\
\hline$\frac{\partial \Delta S}{\partial P}$ & 0.725 & $\mathrm{~mm} \mathrm{a}_{1}^{-1} \mathrm{~mm}^{-1} \mathrm{a}^{-}$ & & & & & 50 & 100 & 36 & 73 & 22 & 59 & 40 \\
\hline
\end{tabular}

tion is much higher than actual evapotranspiration over land. It further assumes that runoff generated from positive values of net precipitation over land areas is routed through rivers and aquifers to the lowest parts of the QB after groundwater reservoirs have been recharged and accumulates there, thus forming new lakes. Then, lake level rises, lake extent and total lake evaporation increase, and the water balance of the entire QB is reduced. The model can thus be applied to assess equilibrium lake states by inverse modelling of lake extent. Based on input data on lake extent, changes in mean annual precipitation in the QB with respect to the present-day situation $\left(200 \mathrm{~mm} \mathrm{a}^{-1}\right)$, and mean annual rate of lake evaporation, it computes the resulting mean annual water balance for the QB and the mean annual change in lake level, which need both to be close to zero for equilibrium lake states (for more details, see the well-documented R source code in the Supplement).

The analysis was performed for three different values for annual lake evaporation, i.e. 600,800 , and $1000 \mathrm{~mm} \mathrm{a}^{-1}$, using lower and upper estimates from the HAR $10 \mathrm{~km}$ data, which are also supported by other studies. Lazhu et al. (2016) report $832 \mathrm{~mm} \mathrm{a}^{-1}$ annual lake evaporation for the lake Nam Co, while Li et al. (2016) measured $824-833 \mathrm{~mm} \mathrm{a}^{-1}$ for the nearby Qinghai Lake. Mean annual lake evaporation in the QB is $649 \mathrm{~mm} \mathrm{a}^{-1}$ according to the HAR $10 \mathrm{~km}$ data set. These results indicate that actual lake evaporation is much less than potential evaporation over lakes (Lazhu et al., 2016; Li et al., 2016).
Projections were also computed for two values of changes in mean annual precipitation of 50 and $100 \mathrm{~mm} \mathrm{a}^{-1}$. These values have been chosen following the results summarized in Table 2. Finally, the change in mean annual precipitation was computed for each of the three values of mean annual lake evaporation such that the maximum extent of the mega-lake system in the QB (see illustration in Fig. 5) of approximately $59000 \mathrm{~km}^{2}$ as reported by Chen and Bowler (1986) would be sustained.

Table 3 summarizes the results from the analysis. The values for the approximate altitudes of lake levels for equilibrium lake states are based on the HAR $10 \mathrm{~km}$ model topography (see also Fig. S10 in the Supplement illustrating different equilibrium lake stands for the results presented in Table 3). Assuming a slight increase in mean annual precipitation of $19 \mathrm{~mm} \mathrm{a}^{-1}$, which is within the error bounds of precipitation in the HAR $10 \mathrm{~km}$ data set, would be sufficient to sustain the present-day lakes in the QB. Even in the most extreme case for the mid-Pliocene, i.e. a rather low increase in mean annual precipitation of only $50 \mathrm{~mm} \mathrm{a}^{-1}$ and a very high rate of mean annual lake evaporation of $1000 \mathrm{~mm} \mathrm{a}^{-1}$, would result in a lake extent of $6654 \mathrm{~km}^{2}$, which is much larger than today's largest lake in China, the Qinghai Lake (about $4300 \mathrm{~km}^{2}$ ). This would require a rise in lake level of only $19 \mathrm{~m}$. Assuming a linear decrease in actual evapotranspiration over time, starting from $40 \mathrm{~mm} \mathrm{a}^{-1}$ until dropping to $0 \mathrm{mma}^{-1}$, the time required to reach the new equilibrium would be approximately 1000 years. On the other hand, a 


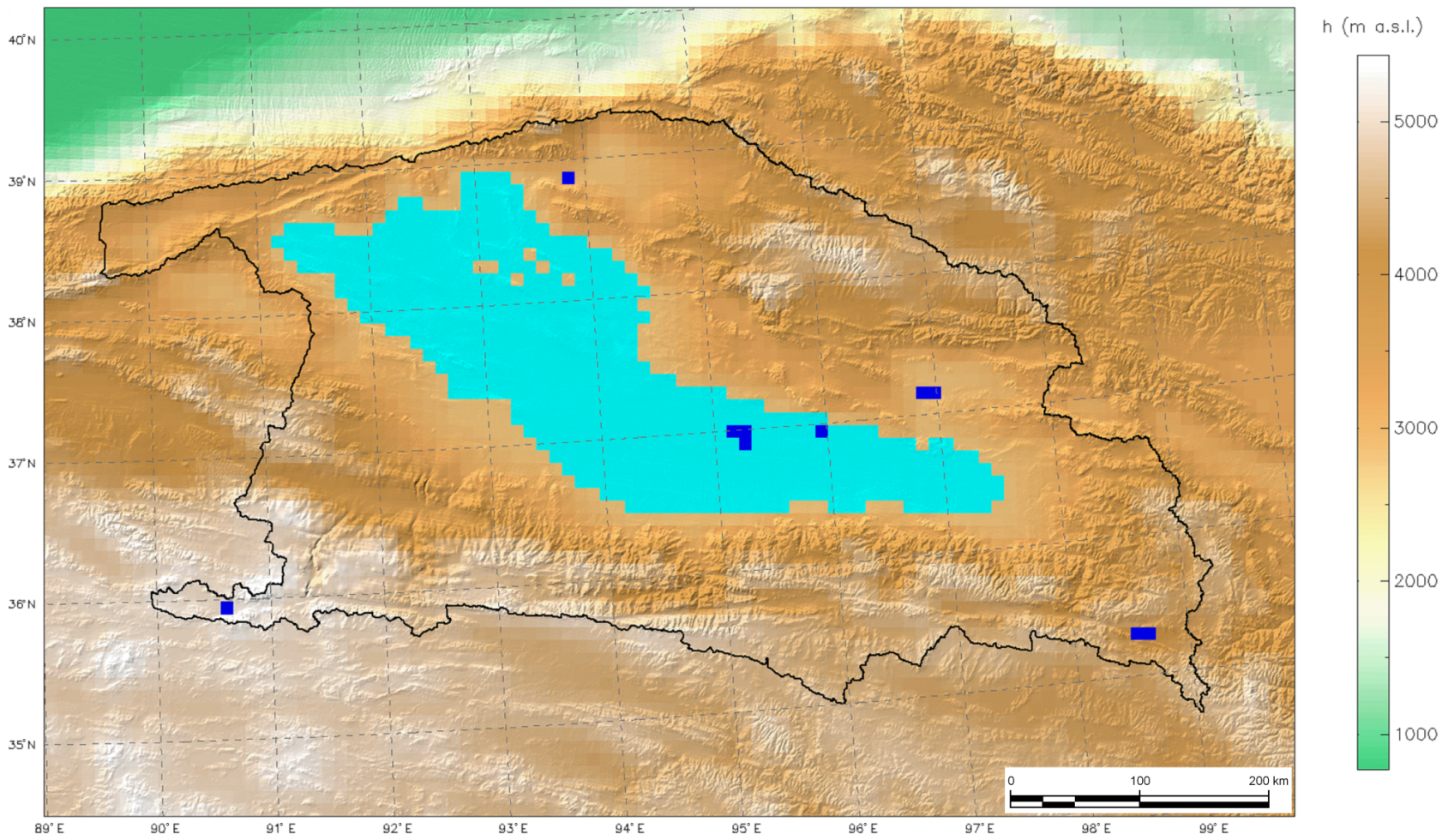

Figure 5. Illustration of the maximum extent of the mega-lake system in the Qaidam Basin (QB) of approximately $59000 \mathrm{~km}^{2}$ as reported by Chen and Bowler (1986) using the present-day model topography of the HAR $10 \mathrm{~km}$ data set for accumulation of net precipitation in the QB and subsequent runoff originating from land in areas at or below $2786 \mathrm{~m}$ a.s.l. (marked in cyan). Black line: boundary of the QB (Lehner and Grill, 2013). Blue: present-day lake extent $\left(1000 \mathrm{~km}^{2}\right)$ as represented in the HAR $10 \mathrm{~km}$ data set. Topographic shading is based on DEM data from the SRTM.

Table 3. Mean annual rate of lake evaporation $\mathrm{ET}_{\text {lake}}$, change in mean annual precipitation $d P_{\mathrm{QB}}$ with respect to present-day precipitation (HAR $10 \mathrm{~km} ; 200 \mathrm{~mm} \mathrm{a}^{-1}$ ), lake extent $A_{\text {lake}}$, and approximate altitude of lake level $z_{\text {lake }}$ for equilibrium lake states in the Qaidam Basin (QB) as computed by a semi-empirical model (cf. R source code in the Supplement). Values in column "HAR" are taken from the HAR $10 \mathrm{~km}$ data set and represent mean annual values for the hydrological years from 2001 to 2014. Table 3 also displays a combination of three projections for $\mathrm{ET}_{\text {lake }}\left(600,800\right.$, and $\left.1000 \mathrm{mma}^{-1}\right)$ and two projections for $d P_{\mathrm{QB}}\left(50\right.$ and $\left.100 \mathrm{mma}^{-1}\right)$. For each of the three projections for $\mathrm{ET}_{\text {lake }}$, the value for $d P_{\mathrm{QB}}$ is shown that would sustain the maximum extent of the mega-lake system in the QB (see Fig. 5). Values for $z$ lake have been computed from the HAR $10 \mathrm{~km}$ model topography by choosing the value that produces a lake extent closest to the equilibrium lake extent as computed by the semi-empirical model.

\begin{tabular}{|c|c|c|c|c|c|c|c|c|c|c|c|}
\hline Quantity & Unit & HAR & & & & & rojection & & & & \\
\hline $\mathrm{ET}_{\text {lake }}$ & $\left(\mathrm{mma}^{-1}\right)$ & 649 & & 600 & & & 800 & & & 1000 & \\
\hline$d P_{\mathrm{OB}}$ & $\left(\mathrm{mma}^{-1}\right)$ & 19 & 50 & 100 & 210 & 50 & 100 & 270 & 50 & 100 & 330 \\
\hline$A_{\text {lake }}$ & $\mathrm{km}^{2}$ & 1000 & 10423 & 25773 & 59000 & 8067 & 19580 & 59000 & 6654 & 15864 & 59000 \\
\hline$z_{\text {lake }}$ & ma.s.l. & 2653 & 2678 & 2711 & 2786 & 2674 & 2698 & 2786 & 2672 & 2688 & 2786 \\
\hline
\end{tabular}

change in mean annual precipitation of $100 \mathrm{mma}^{-1}$, combined with a low rate of mean annual lake evaporation of $600 \mathrm{~mm} \mathrm{a}^{-1}$, would lead to an equilibrium lake state that is characterized by a lake extent of $25.773 \mathrm{~km}^{2}$ and an associated rise in lake level of $58 \mathrm{~m}$. This would be truly a megalake system. Even a high rate of mean annual lake evaporation would result in a lake extent of more than $15.000 \mathrm{~km}^{2}$.
The change in mean annual precipitation required to sustain the maximum extent of the mega-lake system varies between $210 \mathrm{~mm} \mathrm{a}^{-1}$ (for mean annual lake evaporation of $600 \mathrm{mma}^{-1}$ ) and $330 \mathrm{mma}^{-1}$ (for mean annual lake evaporation of $1000 \mathrm{~mm} \mathrm{a}^{-1}$ ). These values are higher than the conservative estimates of this study $\left(50-100 \mathrm{mma}^{-1}\right)$ but still within or nearby the bounds of the studies by R. Zhang et al. (2013) and Mutz et al. (2018). Only the results for 
$1000 \mathrm{mma}^{-1}$ as a value for mean annual lake evaporation are slightly beyond the upper limits given by R. Zhang et al. (2013) and Mutz et al. (2018) for changes in mean annual precipitation $\left(300 \mathrm{~mm} \mathrm{a}^{-1}\right)$. The maximum extent of the mega-lake system would require a rise in lake level of $133 \mathrm{~m}$, and the approximate altitude of the mega-lake system would be $2786 \mathrm{~m}$ a.s.l., which is in accordance with the geological studies on the highest lake levels in the QB. Chen and Bowler (1986) have reported an approximate altitude of the highest lake level of about $2800 \mathrm{~m}$ a.s.l. for the early Pleistocene and of about $2700 \mathrm{~m}$ a.s.l. for the late Pleistocene (see e.g. Fan et al., 2012, for a comprehensive discussion of lake stands in the QB).

Since the high mountain ranges are of utmost importance for the water balance of the entire QB, the question arises as to how different the paleogeographic situation has been in the QB as compared with today. Although the details of tectonics are not yet finally clarified, and vertical movements of the lithosphere have certainly influenced the QB's orography (Fang et al., 2007) and hydrography, the results of this study are considered to be generally applicable to the midPliocene, since the paleogeographic situation has generally been similar to the presence (Dowsett et al., 2010). Since the mid-Miocene, elevations of the QB and surrounding mountain ranges have been comparable to today (C. Wang et al., 2008; Yuan et al., 2013). If altitudes of the high mountain ranges in the QB would have been a few hundred metres lower than today as indicated by Fang et al. (2007), then the negative effect of lower altitudes on annual water balance would be accompanied by the counteracting effect that blocking of humid air masses by the high mountain ranges in the fringes of the QB would have been less strong, a fact also studied for the entire TP (Broccoli and Manabe, 1992). Koutsodendris et al. (2019) state that their results on Late Pliocene vegetation turnover also indicate that terrestrial ecosystem changes in central Asia during this time period were primarily the result of global climate change rather than of Tibetan Plateau uplift.

These statements are justified by the results obtained by applying the same methodology to the HAR data set for the $30 \mathrm{~km}$ domain (see Table S9, Figs. S11 and S12 in the Supplement). Due to the coarser model grid, the altitudes of the highest mountains are lower in the $30 \mathrm{~km}$ grid $\left(h_{\max }=\right.$ $5.136 \mathrm{~m}$ a.s.1.) than in the $10 \mathrm{~km}$ grid $\left(h_{\max }=5.433 \mathrm{~m}\right.$ a.s.1.), and mean annual water balance rises from $-14 \mathrm{mma}^{-1}$ (10 km grid) to $3 \mathrm{~mm} \mathrm{a}^{-1}$ ( $30 \mathrm{~km}$ grid). This indicates that less blocking of humid air inflow to the QB (due to lower altitudes) overcompensates for reduction in orographic precipitation in the HAR $30 \mathrm{~km}$ data set (due to the coarser grid) as compared to the results for the HAR $10 \mathrm{~km}$ data set (higher altitudes and finer grid).

Global climate change as projected for the future and its consequences for the regional climates of China (Burke et al., 2018; Gu et al., 2018; Hui et al., 2018) could lead to strengthening of the East Asian Summer Monsoon (B. Wang et al.,
2008), which could also affect the QB such that both annual specific humidity and precipitation would further increase. This would then lead to continued recharge of groundwater reservoirs and, at a later stage, to rising lake levels or formation of new lakes, as already observed today. In a long-term perspective, even a mega-lake system may be restored.

Assuming a slightly positive long-term mean annual water balance of $20 \mathrm{~mm} \mathrm{a}^{-1}$ as discussed above, lake water levels would rise by $100 \mathrm{~m}$ averaged over the entire QB within only 5000 years, which is, in a geological perspective, a very short time period. Since water would preferentially accumulate in the low-lying areas due to surface and groundwater flows within the QB, the effect would be even stronger in those areas, which have formerly been part of the mega-lake system. As the semi-empirical model shows, the feedback of growing lake area on actual evapotranspiration needs to be taken into account. As long as the lake extent is a small fraction of the entire QB, this feedback is weak. Therefore, lake growth would take place at a high rate in the beginning. During this early stage of lake growth, the rate of mean annual lake evaporation would also be irrelevant since lake growth would be due to runoff from land areas to the lakes.

The particular hypsometric profile of the QB is a major factor for rapid changes in lake extent, as the results in Table 3 indicate. For instance, if lake level would rise from 2672 to $2678 \mathrm{~m}$ a.s.1., i.e. by only $6 \mathrm{~m}$, lake extent would increase from 6654 to $10.423 \mathrm{~km}^{2}$, i.e. by $3769 \mathrm{~km}^{2}$. Partial restoration of the mega-lake system during former Pleistocene interglacial periods as reported by Fan et al. (2012) or Wang et al. (2012), among others, indicates that this mechanism has probably taken place several times in Earth's history.

\section{Conclusions}

This study was able to show that the mean annual water balance of the QB was close to zero during the 14 hydrological years from 2001 to 2014. Negative values of net precipitation prevail in the low-lying desert regions, while the highmountain regions within or at the border of the drainage basin show positive values compensating for water losses at lower altitudes. Orographic precipitation is strongly increasing total precipitation at higher altitudes, while actual evapotranspiration is also increasing with altitude but is less strong. The latter fact, combined with high values of actual evapotranspiration over lakes, indicates that availability of water but not energy for latent heat is the main driver of actual evapotranspiration in the QB.

Annual water balance of the QB was positive during warmer years, since these years showed higher-than-normal precipitation. Annual water balance variations in the QB are driven by variations in annual precipitation, while variations in annual actual evapotranspiration showed no statistically significant effects on annual water balance. The study revealed that not air temperature alone, but specific humid- 
ity, in combination with air temperature, is the main climate driver of annual water balance. Inflow of moister-thannormal air to the QB takes place during warmer-than-normal years and increases both precipitation and water balance.

Even slight changes in specific humidity could induce significant changes in mean annual precipitation and subsequent changes in mean annual water balance, lake levels, and lake extent. The feedback of increased total annual lake evaporation is currently weak but would be the dominant control of lake growth as soon as lakes cover a substantial fraction of the QB. This study, although not targeting reconstruction of paleolakes or making predictions for the future, demonstrates that the maximum extent of the mega-lake system in the QB could have been sustained under climate conditions as reported by paleoclimate studies for the mid-Pliocene. The specific hypsometry of the QB makes it sensitive to rapid changes in lake extent, also under climate conditions projected for the near future.

Future research could target acquisition of additional or improved spatially distributed data sets for water balance components and climate drivers at even higher spatial resolution to capture the details of the high mountain topography of the QB and for longer time periods to improve assessments of environmental changes related to changes in water balance. The new global ERA5 reanalysis data set as well as the transferability of the methods applied in this study to other regions offer new options in this respect. Other lines of research could focus on dynamical downscaling of paleoclimate simulations for Pliocene time slices or global climate projections for the future. Both kinds of data sets are, in general, spatially too coarse to fully resolve atmospheric processes like orographic precipitation or actual evapotranspiration in high mountain ranges (Gu et al., 2018), such that regional water balance computations based on coarse data would, most likely, come with high uncertainties. Thus, dynamical downscaling of global atmospheric data is regarded as essential.

Dynamical downscaling could also be used to study changes in the statistical relations as revealed in this study by artificially modified (paleo-)geographies. Since lakes tend to reduce precipitation while concurrently showing high actual evaporation, there is an upper limit for lake growth, which is, however, difficult to quantify, mainly due to remaining uncertainties of changes in precipitation that have occurred in the QB in geological history or might come with future climate change. High spatial resolution, and thus dynamical downscaling, is also required to quantify whether and how a mega-lake system would effectively recycle its own water, i.e. that atmospheric moisture stemming from lake evaporation precipitates within the basin's catchment area. Water recycling is highly important for the entire TP (Curio et al., 2015) and might also play an important yet unknown role in the QB's water balance.
Code and data availability. The HAR data set is freely available at http://www.klima.tu-berlin.de/HAR (Chair of Climatology, 2020). The source code used in this study for analysing the HAR data is freely available upon request. The source code used for analysing the feedback of changes in lake extent and mean annual precipitation on the mean annual water balance of the QB and changes over lakes and land areas is provided in the Supplement.

Supplement. The supplement related to this article is available online at: https://doi.org/10.5194/hess-24-3835-2020-supplement.

Competing interests. The author declares that there is no conflict of interest.

Acknowledgements. I would like to thank Fabien Maussion (University of Innsbruck, Austria) and Julia Curio (University of Reading, United Kingdom) for their participation in the development of the High Asia Refined analysis data set (HAR) and Erwin Appel, Svetlana Botsyun, Todd Ehlers, and Sebastian Mutz (University of Tübingen) and Marco Otto, Benjamin Schmidt, Vanessa Tolksdorf, and Xun Wang (Technische Universität Berlin, Germany) for collaboration and discussions within the Q-TiP project. My thanks also include the anonymous reviewers and the editor, who substantially helped to improve the study.

Financial support. This work has been supported by the German Research Foundation (DFG) (Priority Programme 1372: "Tibetan Plateau: Formation - Climate - Ecosystems"; project "Dynamic Response of Glaciers on the Tibetan Plateau to Climate Change"; grant nos. SCHE 750/4-1, SCHE 750/4-2, and SCHE 750/4-3) and by the German Federal Ministry of Education and Research (BMBF) (Programme "Central Asia - Monsoon Dynamics and Geo-Ecosystems"; project "Variability and Trends in Water Balance Components of Benchmark Drainage Basins on the Tibetan Plateau"; grant no. 03G0804A; project "Quaternary Tipping Points of Lake Systems in the Arid Zone of Central Asia"; grant no. 03G0863C).

This open-access publication was funded by Technische Universität Berlin.

Review statement. This paper was edited by Bob $\mathrm{Su}$ and reviewed by two anonymous referees.

\section{References}

An, Z., Kutzbach, J. E., Prell, W. L., and Porters, S. C.: Evolution of Asian monsoons and phased uplift of the Himalaya-Tibetan plateau since Late Miocene times, Nature, 411, 62-66, 2001.

Bai, L., Wen, Y., Shi, C., Yang, Y., Zhang, F., Wu, J., Gu, J., Pan, Y., Sun, S., and Meng, J.: Which precipitation product works best in the Qinghai-Tibet Plateau, multi- 
source blended data, global/regional reanalysis data, or satellite retrieved precipitation data?, Remote Sens., 12, 683, https://doi.org/10.3390/rs12040683, 2020.

Broccoli, A. J. and Manabe, S.: The Effects of Orography on Midlatitude Northern Hemisphere Dry Climates, J. Climate, 5, 11811201, 1992.

Burke, K. D., Williams, J. W., Chandler, M. A., Haywood, A. M., Lunt, D. J., and Otto-Bliesner, B. L.: Pliocene and Eocene provide best analogs for near-future climates, P. Natl. Acad. Sci. USA, 115, 13288-13293, 2018.

Cai, M., Fang, X., Wu, F., Miao, Y., and Appel, E.: PliocenePleistocene stepwise drying of Central Asia: Evidence from paleomagnetism and sporopollen record of the deep borehole SG-3 in the western Qaidam Basin, NE Tibetan Plateau, Global Planet. Change, 94-95, 72-81, 2012

Chair of Climatology: Technische Universität Berlin, The High Asia Refined analysis (HAR), available at: https://www.klima. tu-berlin.de/HAR, last access: 27 July 2020.

Chandan, D. and Peltier, W. R.: On the mechanisms of warming the mid-Pliocene and the inference of a hierarchy of climate sensitivities with relevance to the understanding of climate futures, Clim. Past, 14, 825-856, https://doi.org/10.5194/cp-14825-2018, 2018.

Chen, K. and Bowler, J. M.: Late pleistocene evolution of salt lakes in the Qaidam basin, Qinghai province, China, Paleogeogr. Paleocl., 54, 87-104, 1986.

Curio, J., Maussion, F., and Scherer, D.: A 12-year highresolution climatology of atmospheric water transport over the Tibetan Plateau, Earth Syst. Dynam., 6, 109-124, https://doi.org/10.5194/esd-6-109-2015, 2015.

Dowsett, H., Robinson, M., Haywood, A., Salzmann, U., Hill, D., Sohl, L., Chandler, M., Williams, M., Foley, K., and Stoll, D.: The PRISM3D paleoenvironmental reconstruction, Stratigraphy, 7, 123-139, 2010.

Fan, Q., Ma, H., Cao, G., Chen, Z., and Cao, S.: Geomorphic and chronometric evidence for high lake level history in Gahai Lake and Toson Lake of north-eastern Qaidam Basin, north-eastern Qinghai-Tibetan Plateau, J. Quat. Sci., 27, 819-827, 2012.

Fang, X., Zhang, W., Meng, Q., Gao, J., Wang, X., King, J., Song, C., Dai, S., and Miao, Y.: High-resolution magnetostratigraphy of the Neogene Huaitoutala section in the eastern Qaidam Basin on the NE Tibetan Plateau, Qinghai Province, China and its implication on tectonic uplift of the NE Tibetan Plateau, Earth Planet. Sc. Lett., 258, 293-306, 2007.

Fang, X., Li, M., Wang, Z., Wang, J., Li, J., Liu, X., and Zan, J.: Oscillation of mineral compositions in Core SG-1b, western Qaidam Basin, NE Tibetan Plateau. Sci. Rep.-UK, 6, 32848, https://doi.org/10.1038/srep32848, 2016.

Greve, P., Gudmundsson, L., and Seneviratne, S. I.: Regional scaling of annual mean precipitation and water availability with global temperature change, Earth Syst. Dynam., 9, 227-240, https://doi.org/10.5194/esd-9-227-2018, 2018

Gu, H., Yu, Z., Yang, C., Ju, Q., Yang, T., and Zhang, D.: High-resolution ensemble projections and uncertainty assessment of regional climate change over China in CORDEX East Asia, Hydrol. Earth Syst. Sci., 22, 3087-3103, https://doi.org/10.5194/hess-22-3087-2018, 2018.

Haywood, A. M., Hill, D. J., Dolan, A. M., Otto-Bliesner, B. L., Bragg, F., Chan, W.-L., Chandler, M. A., Contoux, C., Dowsett,
H. J., Jost, A., Kamae, Y., Lohmann, G., Lunt, D. J., Abe-Ouchi, A., Pickering, S. J., Ramstein, G., Rosenbloom, N. A., Salzmann, U., Sohl, L., Stepanek, C., Ueda, H., Yan, Q., and Zhang, Z.: Large-scale features of Pliocene climate: results from the Pliocene Model Intercomparison Project, Clim. Past, 9, 191-209, https://doi.org/10.5194/cp-9-191-2013, 2013.

Haywood, A. M., Dowsett, H. J., and Dolan, A. M.: Integrating geological archives and climate models for the mid-Pliocene warm period, Nat. Commun., 7, 10646, https://doi.org/10.1038/ncomms10646, 2016.

Heermance, R. V., Pullen, A., Kapp, P., Garzione, C. N., Bogue, S., Ding, L., and Song, P.: Climatic and tectonic controls on sedimentation and erosion during the Pliocene-Quaternary in the Qaidam Basin (China), GSA Bulletin, 125, 833-856, 2013.

Huang, Q., Ku, T.-L., and Phillips, F. M.: Evolutionary characteristics of lakes and palaeoclimatic undulations in the Qaidam Basin, China, Chin. J. Oceanol. Limnol., 11, 34-45, 1993.

Hui, P., Tang, J., Wang, S., Niu, X., Zong, P., and Dong, X.: Climate change projections over China using regional climate models forced by two CMIP5 global models. Part II: projections of future climate, Int. J. Climatol., 38, e78-e94, 2018.

Jiao, J. J., Zhang, X, Liu, Y., and Kuang, X.: Increased water storage in the Qaidam Basin, the north Tibet Plateau from GRACE gravity data, PLoS ONE, 10, e0141442, https://doi.org/10.1371/journal.pone.0141442, 2015.

Jin, X., Guo, R., and Xia, W.: Distribution of actual evapotranspiration over Qaidam Basin, an arid area in China, Remote Sens., 5, 6976-6996, 2013.

Kang, S., Xu, Y., You, Q., Flügel, W.-A., Pepin, N., and Yao, T.: Review of climate and cryospheric change in the Tibetan Plateau, Environ. Res. Lett., 5, 015101, https://doi.org/10.1088/17489326/5/1/015101, 2010.

Koutsodendris, A., Allstädt, F. J., Kern, O. A., Kousis, I., Schwarz, F., Vannacci, M., Woutersen, A., Appel, E., Berke, M. A., Fang, X., Friedrich, O., Hoorn, C., Salzmann, U., and Pross, J.: Late Pliocene vegetation turnover on the NE Tibetan Plateau (Central Asia) triggered by early Northern Hemisphere glaciation, Global Planet. Change, 180, 117-125, 2019.

Lazhu, Yang, K., Wang, J., Lei, Y., Chen, Y., Zhu, L., Ding, B., and Qin, J.: Quantifying evaporation and its decadal change for Lake Nam Co, central Tibetan Plateau, J. Geophys. Res.-Atmos., 121, 7578-7591, 2016.

Lehner, B. and Grill, G.: Global river hydrography and network routing: baseline data and new approaches to study the world's large river systems, Hydrol. Process., 27, 2171-2186, 2013.

Lei, Y., Yang, K., Wang, B., Sheng, Y., Bird, B. W., Zhang, G., and Tian, L.: Response of inland lake dynamics over the Tibetan Plateau to climate change, Clim. Change, 125, 281-290, 2014.

Li, D., Yang, K., Tang, W., Li, X., Zhou, X., and Guo, D.: Characterizing precipitation in high altitudes of the western Tibetan plateau with a focus on major glacier areas, Int. J. Climatol., 114, https://doi.org/10.1002/joc.6509, 2020.

Li, L., Yang, S., Wang, Z., Zhu, X., and Tang, H.: Evidence of warming and wetting climate over the Qinghai-Tibet Plateau, Arct. Antarct. Alp. Res., 42, 449-457, 2010.

Li, H., Mao, D., Li, X., Wang, Z., and Wang, C.: Monitoring 40-Year Lake Area Changes of the Qaidam Basin, Tibetan Plateau, Using Landsat Time Series, Remote Sens., 11, 343, https://doi.org/10.3390/rs11030343, 2019. 
Li, X.-Y., Ma, Y.-J., Huang, Y.-M., Hu, X., Wu, X.-C., Wang, P., Li, G.-Y., Zhang, S.-Y., Wu, H. W., Jiang, Z.-Y., Cui, B.-L., and Liu, L.: Evaporation and surface energy budget over the largest high-altitude saline lake on the Qinghai-Tibet Plateau, J. Geophys. Res.-Atmos., 121, 10470-10485, 2016.

Li, Y., Su, F., Chen, D., and Tang, Q.: Atmospheric Water Transport to the Endorheic Tibetan Plateau and Its Effect on the Hydrological Status in the Region, J. Geophys. Res.-Atmos., 124, 12864-12881, 2019.

Liu, X. and Chen, B.: Climatic warming in the Tibetan Plateau during recent decades, Int. J. Climatol., 20, 1729-1742, 2000.

Loomis, B. D., Richey, A. S., Arendt, A. A., Appana, R., Deweese, Y.-J. C., Forman, B. A., Kumar, S. V., Sabaka, T. J., and Shean, D. E.: Water Storage Trends in High Mountain Asia, Front. Earth Sci., 7, 235, https://doi.org/10.3389/feart.2019.00235, 2019.

Madsen, D. B., Lai, Z., Sun, Y., Rhode, D., Liu, X., and Brantingham, P. J.: Late Quaternary Qaidam lake histories and implications for an MIS 3 "Greatest Lakes" period in northwest China, J. Paleolimnol., 51, 161-177, 2014.

Maussion, F., Scherer, D., Finkelnburg, R., Richters, J., Yang, W., and Yao, T.: WRF simulation of a precipitation event over the Tibetan Plateau, China - an assessment using remote sensing and ground observations, Hydrol. Earth Syst. Sci., 15, 1795-1817, https://doi.org/10.5194/hess-15-1795-2011, 2011.

Maussion, F., Scherer, D., Mölg, T., Collier, E., Curio, J., and Finkelnburg, R.: Precipitation seasonality and variability over the Tibetan Plateau as resolved by the High Asia Reanalysis, J. Climate, 27, 1910-1927, 2014.

Miao, Y. F., Fang, X. M., Wu, F. L., Cai, M. T., Song, C. H., Meng, Q. Q., and $\mathrm{Xu}, \mathrm{L}$. .: Late Cenozoic continuous aridification in the western Qaidam Basin: evidence from sporopollen records, Clim. Past, 9, 1863-1877, https://doi.org/10.5194/cp-91863-2013, 2013.

Mischke, S., Sun, Z., Herzschuh, U., Qiao, Z., and Sun, N.: An ostracod-inferred large Middle Pleistocene freshwater lake in the presently hyper-arid Qaidam Basin (NW China), Quat. Int., 218, 74-85, 2010.

Mölg, T., Maussion, F., and Scherer, D.: Mid-latitude westerlies as a driver of glacier variability in monsoonal High Asia, Nat. Clim. Change, 4, 68-73, 2014.

Morrow, E., Mitrovica, J. X., and Fotopoulos, G.: Water storage, net precipitation, and evapotranspiration in the Mackenzie River Basin from October 2002 to September 2009 inferred from GRACE satellite gravity data, J. Hydrometeorol., 12, 467-473, 2011.

Mutz, S. G., Ehlers, T. A., Werner, M., Lohmann, G., Stepanek, C., and $\mathrm{Li}, \mathrm{J} .:$ Estimates of late Cenozoic climate change relevant to Earth surface processes in tectonically active orogens, Earth Surf. Dynam., 6, 271-301, https://doi.org/10.5194/esurf-6-2712018, 2018.

Pritchard, D. M., Forsythe, N., Fowler, H. J., O’Donnell, G. M., and Li, X.: Evaluation of Upper Indus near-surface climate representation by WRF in the High Asia Refined Analysis, J. Hydrometeorol., 20, 467-487, 2019.

$\mathrm{Su}, \mathrm{Z}$. : The Surface Energy Balance System (SEBS) for estimation of turbulent heat fluxes, Hydrol. Earth Syst. Sci., 6, 85-100, https://doi.org/10.5194/hess-6-85-2002, 2002.

Wan, W., Long, D., Hong, Y., Ma, Y., Yuan, Y., Xiao, P., Duan, H., Han, Z., and Gu, X.: A lake data set for the Tibetan Plateau from the 1960s, 2005, and 2014, Scientific data, 3, 160039, https://doi.org/10.1038/sdata.2016.39, 2016.

Wang, B., Bao, Q., Hoskins, B., Wu, G., and Liu, Y.: Tibetan Plateau warming and precipitation changes in East Asia, Geophys. Res. Lett., 35, L14702, https://doi.org/10.1029/2008GL034330, 2008.

Wang, C., Zhao, X., Liu, Z., Lippert, P. C., Graham, S. A., Coe, R. S., Yi, H., Zhu, L., Liu, S., and Li, Y.: Constraints on the early uplift history of the Tibetan Plateau, P. Natl. Acad. Sci. USA, 105, 4987-4992, 2008.

Wang, J. Y., Fang, X., Appel, E., and Song, C.: Pliocene-Pleistocene climate change at the NE Tibetan Plateau deduced from lithofacies variation in the drill core SG-1, western Qaidam Basin, J. Sediment. Res., 82, 933-952, 2012.

Wang, X., Yang, M., Liang, X., Pang, G., Wan, G., Chen, X., and Luo, X.: The dramatic climate warming in the Qaidam Basin, northeastern Tibetan Plateau, during 1961-2010, Int. J. Climatol., 34, 1524-1537, 2014.

Wu, F. L., Fang, X., Herrmann, M., Mosbrugger, V., and Miao, Y. F.: Extended drought in the interior of Central Asia since the Pliocene reconstructed from sporopollen records, Global Planet. Change, 76, 16-21, 2011.

$\mathrm{Xu}, \mathrm{X} ., \mathrm{Lu}, \mathrm{C}$., Shi, X., and Gao, S.: World water tower: An atmospheric perspective, Geophys. Res. Lett., 35, L20815, https://doi.org/10.1029/2008GL035867, 2008.

Yang, K., Wu, H., Qin, J., Lin, C., Tang, W., and Chen, Y.: Recent climate changes over the Tibetan Plateau and their impacts on energy and water cycle: A review, Global Planet. Change, 112, 79-91, 2014.

Yoon, Y., Kumar, S. V., Forman, B. A., Zaitchik, B. F., Kwon, Y., Qian, Y., Rupper, S., Maggioni, V., Houser, P., Kirschbaum, D., Richey, A., Arendt, A., Mocko, D., Jacob, J., Bhanja, S., and Mukherjee, A.: Evaluating the Uncertainty of Terrestrial Water Budget Components Over High Mountain Asia, Front. Earth Sci., 7, 120, https://doi.org/10.3389/feart.2019.00120, 2019.

Yu, S.-Y., Colman, S. M., and Lai, Z.-P.: Late-Quaternary history of "great lakes" on the Tibetan Plateau and paleoclimatic implications - A review, Boreas, 48, 1-19, 2019.

Yuan, D. Y., Ge, W. P., Chen, Z. W., Li, C. Y., Wang, Z. C., Zhang, H. P., Zhang, P. Z., Zheng, D. W., Zheng, W. J., Craddock, W. H., Dayem, K. E., Duvall, A. R., Hough, B. G., Lease, R. O., Champagnac, J. D., Burbank, D. W., Clark, M. K., Farley, K. A., Garzione, C. N., Kirby, E., Molnar, P., and Dayem, K. E.: The growth of northeastern Tibet and its relevance to large-scale continental geodynamics: a review of recent studies, Tectonics, 32, 1358-1370, 2013.

Zhang, G., Xie, H., Kang, S., Yi, D., and Ackley, S. F.: Monitoring lake level changes on the Tibetan Plateau using ICESat altimetry data (2003-2009), Remote Sens. Environ., 115, 1733-1742, 2011.

Zhang, G., Yao, T., Xie, H., Kang, S., and Lei, Y.: Increased mass over the Tibetan Plateau: From lakes or glaciers?, Geophys. Res. Lett., 40, 2125-2130, 2013.

Zhang, G., Yao, T., Shumm, C. K., Yi, S., Yang, K., Xie, H., Feng, W., Bolch, T., Wang, L., Behrangi, A., Zhang, H., Wang, C., Xiang, Y., and Yu, J.: Lake volume and groundwater storage variations in Tibetan Plateau's endorheic basin, Geophys. Res. Lett., 44, 5550-5560, 2017.

Zhang, L., Guo, H., Ji, L., Wang, C., Yan, D., Li, B., and Li, J.: Vegetation greenness trend (2000 to 2009) and the climate controls 
in the Qinghai-Tibetan Plateau, J. Appl. Rem. Sens., 7, 073572, https://doi.org/10.1117/1.JRS.7.073572, 2013.

Zhang, R., Yan, Q., Zhang, Z. S., Jiang, D., Otto-Bliesner, B. L., Haywood, A. M., Hill, D. J., Dolan, A. M., Stepanek, C., Lohmann, G., Contoux, C., Bragg, F., Chan, W.-L., Chandler, M. A., Jost, A., Kamae, Y., Abe-Ouchi, A., Ramstein, G., Rosenbloom, N. A., Sohl, L., and Ueda, H.: Mid-Pliocene East Asian monsoon climate simulated in the PlioMIP, Clim. Past, 9, 20852099, https://doi.org/10.5194/cp-9-2085-2013, 2013.
Zubakov, V. A. and Borzenkova, I. I.: Pliocene palaeoclimates: past climates as possible analogues of mid-twenty-first century climate, Palaeogeogr. Palaeocl., 65, 35-49, 1988. 